\title{
FAKTOR-FAKTOR YANG MEMPENGARUHI MINAT BELI KONSUMEN GENERASI Y DAN Z PADA PRODUK MAKANAN KETUCKY FRIED CHICKEN
}

\author{
Selvi Selvi dan Carunia Mulya Firdausy
}

\section{Program Studi Manajemen Fakultas Ekonomi Universitas Tarumanagara, Jakarta}

Email: selvi.115160057@stu.untar.ac.id

\begin{abstract}
The brand value of KFC occupy number three in the world and number two in Indonesia. It means that KFC is quite popular among Indonesian people. This research aims to test whether brand image variable, E-WOM, and social media usage of Instagram have a positive relationship towards purchase intention in generation $Y$ and $Z$ on KFC food products at Citra Garden 6, West Jakarta. This study used 100 samples with a convenience sampling method. Data retrieval techniques are performed using questionnaires and analyzed using PLSSEM. The results showed indicate brand image variable and social media usage had a positive relationship with purchase intention, whereas E-WOM variable had no positive relationship towards purchase intention.
\end{abstract}

Keywords: Brand Image, E-WOM, Social Media Usage, Purchase Intention.

Abstrak: Nilai merek KFC menempati posisi nomor tiga di dunia dan nomor dua di Indonesia. Hal ini berarti bahwa KFC cukup popular di kalangan masyarakat Indonesia. Penelitian ini bertujuan untuk menguji apakah variabel citra merek, E-WOM, dan penggunaan media sosial Instagram memiliki hubungan positif terhadap minat beli konsumen generasi $\mathrm{Y}$ dan $\mathrm{Z}$ pada produk makanan KFC di Citra Garden 6, Jakarta Barat. Penelitian ini menggunakan 100 sampel dengan metode convenience sampling. Teknik pengambilan data dilakukan dengan menggunakan kuesioner dan dianalisis menggunakan PLS-SEM. Hasil penelitian ini menunjukkan bahwa variabel citra merek dan penggunaan media sosial memiliki hubungan positif dengan minat beli, sedangkan variabel E-WOM tidak memiliki hubungan positif terhadap minat beli.

Kata Kunci: Citra Merek, E-WOM , Penggunaan Media Sosial, Minat Beli.

\section{LATAR BELAKANG}

Makanan merupakan kebutuhan pokok penting untuk manusia. Dalam kehidupan modern ini, manusia sangat selektif dalam memilih makanan. Oleh karena itu, kebutuhan pangan bisa menjadi satu peluang untuk bisnis di bidang kuliner.

Databoks mengatakan bahwa nilai merek KFC saat ini menduduki nomor tiga di dunia. Menurut Tribuntravel.com, KFC menempati nomor dua yang paling banyak diminati oleh 
masyarakat Indonesia setelah Restoran Sederhana. Walaupun nilai merek KFC menduduki nomor tiga di dunia, akan tetapi masyarakat Indonesia sangat menggemari KFC karena rasa dan inovasi yang menyesuaikan selera sehingga banyak konsumen yang berminat membeli produk KFC.

Dengan adanya perkembangan teknologi informasi dan komunikasi saat ini, generasi Y dan Z menyukai memesan makanan dari luar dikarenakan tidak bisa memasak dan tidak ada makanan di rumah. Oleh karena itu, KFC menghadirkan banyak promo di media sosial Instagram untuk memicu minat beli mereka. Selain itu, terdapat website yang tertera pada akun Instagram KFC yang memudahkan generasi $\mathrm{Y}$ dan $\mathrm{Z}$ dalam memesan makanan melalui website ini.

Minat beli konsumen generasi $\mathrm{Y}$ dan $\mathrm{Z}$ dapat ditingkatkan dengan banyak cara seperti meningkatkan citra merek, memberikan ulasan yang positif, dan meningkatkan penggunaan media sosial terhadap produk makanan KFC di Citra Garden 6, Jakarta Barat.

Berdasarkan latar belakang atau fenomena tersebut, dan adanya penelitian terdahulu mengenai hal tersebut. Penelitian ini bertujuan untuk menginvestigasi apakah minat beli konsumen generasi $\mathrm{Y}$ dan $\mathrm{Z}$ dipengaruhi oleh citra merek, E-WOM, dan penggunaan media sosial akan tetapi penelitian ini belum banyak dilakukan sehingga peneliti berharap peneliti selanjutnya dapat mengkaji variabel variabel yang terdapat di dalamnya.

\section{LANDASAN TEORI}

Theory of Planned Behaviour. Penelitian ini didasarkan pada Theory of Planned Behaviour. Menurut Ajzen (1991), Theory of Planned Behaviour merupakan teori yang dikembangkan dari Theory of Reasoned Action yang dibuat oleh keterbatasan model asli dalam menangani perilaku di mana orang memiliki kontrol atas kehendak yang tidak lengkap. Teori ini membahas mengenai niat individu melakukan perilaku tertentu. Adapun 3 faktor penentu dalam niat konseptual yang independen yakni sikap, norma subjektif dan kontrol perilaku.

Generasi Y. Generasi Y merupakan kelompok generasi kelahiran tahun 1980-1995 (25-40 tahun). Generasi ini banyak menggunakan teknologi komunikasi instan seperti email, SMS, instant messaging dan media sosial seperti facebook dan twitter. Dengan kata lain generasi Y adalah generasi yang tumbuh pada era internet booming (Lyons, dalam Putra 2017). 
Generasi Z. Generasi Z merupakan tahun kelahiran 1996-2010 (10-24 tahun). Generasi ini sudah terbiasa dengan teknologi canggih dan mampu mengaplikasikan semua kegiatan dalam satu waktu (multi tasking) seperti: menjalankan sosial media menggunakan ponsel, browsing menggunakan PC, dan mendengarkan musik menggunakan headset (Putra, 2017).

Citra Merek. Citra merek adalah persepsi konsumen yang mengarah pada sebuah identitas biasanya dalam bentuk simbol atau logo yang tersimpan dalam memori konsumen. Penelitian ini telah dilakukan sebelumya oleh Jalilvand \& Samiei 2012 mengatakan dalam memperbaiki sebuah citra merek dapat dilakukan dengan meningkatkan berbagai produk, meningkatkan kualitas produk, menawarkan produk dalam harga yang layak, dan menyediakan layanan purna jual sehingga dapat meningkatkan minat beli. Kemudian penelitian yang dilakukan oleh Setiawaty (2017) menjelaskan bahwa instansi yang memiliki citra merek yang baik akan membentuk suatu keunggulan tersendiri dari pesaing- pesaing lainnya, keunikan dari suatu produk juga dapat menarik minat beli konsumen. Rifai et al. (2016) juga menjelaskan bahwa citra positif yang terdapat pada suatu merek menjadikan konsumen tidak ragu untuk memiliki niat membeli. Hal tersebut berarti jika perluasan merek yang sudah dikenal baik konsumen meningkat, citra merek akan semakin membaik sehingga akan memberikan pengaruh terhadap minat beli.

Electronic Word of Mouth (E-WOM). E-WOM dapat diartikan sebagai media komunikasi dalam pertukaran informasi secara online mengenai produk atau jasa. Studi ini telah dilakukan sebelumnya oleh Jalilvand \& Samiei (2012) menjelaskan bahwa membaca rekomendasi online untuk produk mereka tertarik secara langsung pada titik pembelian yang mungkin memiliki efek yang kuat pada minat dalam mengambil keputusan pembelian mereka. Selanjutnya, See-To \& Ho (2014) menjelaskan bahwa E-WOM dapat mempengaruhi minat beli melalui beberapa saluran yakni dampak langsung, memoderasikan oleh berbagai aspek kepercayaan dan memoderasikan dengan nilai proses pembuatan bersama. Begitu pula dengan Widjaja (2016) menjelaskan bahwa penggunaan telepon genggam pintar yang mendukung konsumen untuk aktif menggunakan internet dan media sosial membuat aktivitas mencari informasi mengenai produk meningkat sebelum pembelian pula seperti misalnya melihat ulasan pada situs, forum, blog, atau media sosial itu sendiri dengan melihat apa yang di-post atau reply oleh teman. 
Penggunaan Media Sosial. Penggunaan media sosial adalah sebuah platform online yang di mana konsumen dapat mengakses, berbagi, menciptakan informasi dan konten. Penelitian ini sudah dikaji oleh Indika \& Jovita (2017) menjelaskan bahwa penggunaan media sosial yang menonjolkan sharing foto atau gambar terbukti mempunyai korelasi kuat dalam memengaruhi minat beli konsumen. Setelah itu, Setiawati \& Aida (2017) juga menjelaskan bahwa penggunaan media sosial sebagai salah satu alat atau metode yang cukup mudah untuk diakses dalam alternatif pilihan berbelanja. Prasad et al. (2019) dalam penelitiannya menjelaskan bahwa penggunaan media sosial memiliki dampak yang signifikan secara langsung pada minat beli. Adapun sebuah studi yang mendukung penelitian ini memperkirakan bahwa kegiatan media sosial memengaruhi persepsi tentang merek oleh sebab itu dapat mempengaruhi proses keputusan pembelian.

\section{Kerangka Pemikiran}

Gambar 1. Kerangka Pemikiran

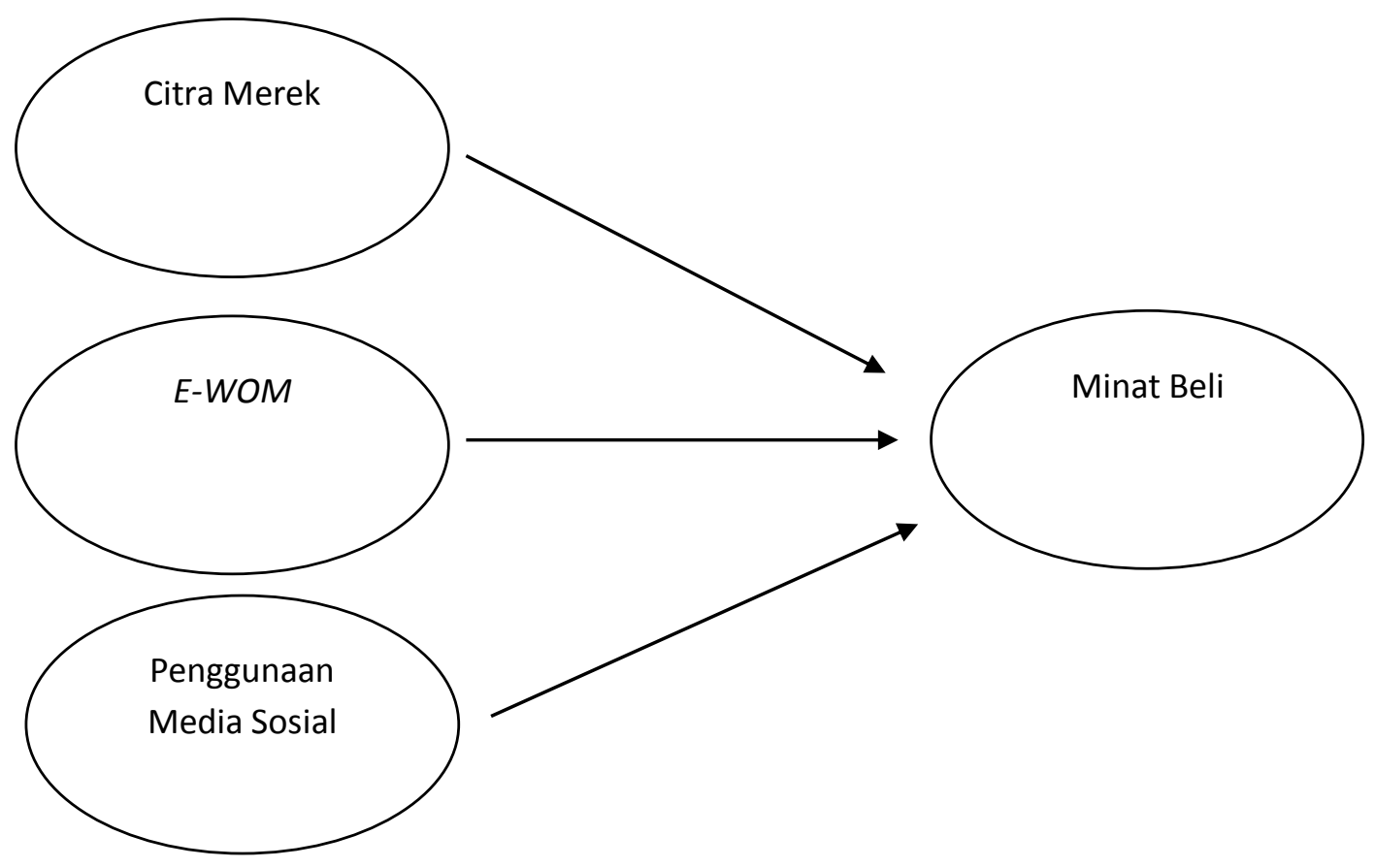

Berdasarkan kerangka pemikiran di atas, dapat disusun hipotesis penelitian sebagai berikut:

H1: Citra Merek berpengaruh signifikan dan positif terhadap minat beli. 
H2: $E-W O M$ berpengaruh signifikan dan positif terhadap minat beli.

H3:Penggunaan Media Sosial berpengaruh signifikan dan positif terhadap minat beli.

\section{METODE PENELITIAN}

Penelitian ini bersifat penelitian deskriptif. Penelitian deskriptif ini bertujuan untuk menyelidiki suatu fenomena atau faktor dan menilai hubungan suatu faktor dengan faktor lain. Dalam penelitian ini, data yang diperoleh dari lapangan analisis dengan cara menjelaskan temuan data dan hasil analisis menggunakan metode statistik yang digunakan.

Populasi dalam penelitian ini adalah konsumen generasi Y dan Z. Generasi Y berkisaran usia 25-40 tahun sedangkan generasi Z berkisaran usia 10-24 tahun. Penelitian ini dilakukan di Citra Garden 6, Jakarta Barat.

Penelitian ini menggunakan teknik non-probability sampling. Dengan kata lain, teknik pengambilan sampel yang tidak memberi peluang atau kesempatan sama bagi setiap unsur atau anggota populasi untuk dipilih menjadi sampel. Sedangkan, dalam pengumpulan dilapangan responden yang menjadi sampel dilakukan dengan cara convenience sampling yakni memilih sampel berdasarkan konsumen generasi Y dan Z. Peneliti menggunakan teknik ini karena cepat serta menghemat waktu dan biaya.

Jumlah responden yang menjadi sampel yakni 100 orang. Peneliti mengumpulkan data dengan cara membuat kuesioner pada google form dan menyebarkan dengan menghubungi konsumen secara personal generasi $\mathrm{Y}$ dan $\mathrm{Z}$ yang tinggal di daerah sekitar Citra Garden 6 melalui Whatsapp dan Instagram.

\section{HASIL ANALISIS DATA}

\section{Hasil analisis validitas}

Validitas Konvergen. Hasil analisis validitas konvergen menunujukkan bahwa semua variabel memiliki nilai $A V E$ lebih besar dari 0.5. Dengan demikian keempat variabel tersebut memenuhi persyaratan dari convergent validity. 
Tabel 1. Hasil Validitas Konvergen

\begin{tabular}{|l|l|}
\hline \multicolumn{1}{|c|}{ Variabel } & \multicolumn{1}{c|}{ AVE } \\
\hline Citra Merek & 0.502 \\
\hline E-WOM & 0.578 \\
\hline Minat Beli & 0.565 \\
\hline Penggunaan Media Sosial & 0.588 \\
\hline
\end{tabular}

Sumber: Data diolah dari Smart PLS

Validitas Diskriminan. Hasil analisis discriminant validity yang diukur dengan pendekatan Fornell-Lacker menunjukkan bahwa variabel citra merek, minat beli dan penggunaan media sosial mampu menjelaskan variabel itu sendiri lebih besar dibandingkan variabel lainnya kecuali variabel $E$-WOM di mana memiliki nilai lebih kecil dibandingkan variabel penggunaan media sosial.

Tabel 2. Hasil Fornell-Lacker

\begin{tabular}{|l|c|c|c|c|}
\hline & Citra merek & $E$-WOM & Minat Beli & $\begin{array}{c}\text { Penggunaan } \\
\text { Media Sosial }\end{array}$ \\
\hline Citra Merek & 0.708 & & & \\
\hline$E$-WOM & 0.350 & 0.760 & & \\
\hline Minat Beli & 0.682 & 0.669 & 0.752 & \\
\hline $\begin{array}{l}\text { Penggunan Media } \\
\text { Sosial }\end{array}$ & 0.304 & 0.838 & 0.665 & 0.767 \\
\hline
\end{tabular}

Sumber: Data diolah dari Smart PLS

\section{Hasil Analisis Realibilitas}

Hasil analisis reliabilitas yang diukur dengan composite reliability, citra merek, E-WOM, penggunaan media sosial dan minat beli memiliki nilai lebih dari 0.7 .

Tabel 3. Hasil Composite Realibility

\begin{tabular}{|l|c|}
\hline \multicolumn{1}{|c|}{ Variabel } & Composite Reliability \\
\hline Citra Merek & 0.855 \\
\hline E-WOM & 0.891 \\
\hline Minat Beli & 0.886 \\
\hline Penggunaan Media Sosial & 0.877 \\
\hline
\end{tabular}

Sumber: Data diolah dari Smart PLS 
Hasil Analisis Multikoneritas. Hasil analisis multikoneritas menjelaskan bahwa variabel citra merek, E-WOM, dan penggunaan media sosial memiliki nilai VIF $<5$ yang berarti tidak ada multikoneritas.

Tabel 4. Hasil Analisis Multikoneritas

\begin{tabular}{|l|c|}
\hline \multicolumn{1}{|c|}{ Variabel } & $\begin{array}{c}\text { Variance Inflation Factor } \\
(\text { VIF })\end{array}$ \\
\hline Citra Merek & 1.140 \\
\hline E-WOM & 3.472 \\
\hline Penggunaan Media Sosial & 3.358 \\
\hline
\end{tabular}

Sumber: Data diolah dari Smart PLS

Analisis Path Coefficient. Pada hasil uji path coefficient menunjukkan bahwa variabel citra merek, E-WOM dan penggunaan media sosial terhadap minat beli memiliki nilai path coefficient positif di mana nilai masing-masing adalah 0.506, 0.212, dan 0.333.

Tabel 5. Hasil Path Coefficient

\begin{tabular}{|l|c|}
\hline & Minat Beli \\
\hline Citra Merek & 0.506 \\
\hline E-WOM & 0.212 \\
\hline Penggunaan Media Sosial & 0.333 \\
\hline
\end{tabular}

Sumber: Data diolah dari Smart PLS

Analisis Koefisien Determinasi. Hasil analisis koefisien determinasi pada minat beli sebesar 0.709 yang memiliki arti 70.9 persen variabel minat beli dipengaruhi oleh citra merek, E-WOM, dan penggunaan media sosial, sisanya 29.1 persen dipengaruhi oleh faktor- faktor lain. Korelasi penggunaan media sosial, citra merek dan E-WOM yang menjelaskan mengenai minat beli ini tergolong sedang.

Tabel 6. Hasil Analisis Koefisien Determinasi

\begin{tabular}{|c|c|}
\hline Variabel & R Square \\
\hline Minat Beli & 0.709 \\
\hline
\end{tabular}

Sumber: Data diolah dari Smart PLS

Analisis Effect Size. Hasil analisis effect size dapat disimpulkan bahwa pengaruh variabel citra merek terhadap minat beli memiliki korelasi kuat sebesar 0.711. Sementara E-WOM dan penggunaan media sosial memiliki korelasi lemah terhadap minat beli sebesar 0.045 dan 0.114. 
Tabel 7. Hasil Analisis Effect Size

\begin{tabular}{|l|c|}
\hline & Minat Beli \\
\hline Citra Merek & 0.771 \\
\hline E-WOM & 0.045 \\
\hline Penggunaan Media Sosial & 0.114 \\
\hline
\end{tabular}

Sumber: Data diolah dari Smart PLS

Analisis Predictive Relevance. Hasil analisis predictive relevance menyimpulkan bahwa hubungan variabel dalam penelitian ini dianggap relevan karena hasil Q square menujukkan lebih dari 0.

Tabel 8. Hasil Analisis Predictive Relevance

\begin{tabular}{|c|c|}
\hline Variabel & Q Square \\
\hline Minat Beli & 0.381 \\
\hline
\end{tabular}

Sumber: Data diolah dari Smart PLS

Pengujian Hipotesis. Pengujian hipotesis pada penelitian ini bertujuan untuk mengetahui apakah hipotesis yang terdapat pada penelitian ini ditolak atau tidak ditolak dengan memperhatikan nilai $t$-statistic pada path coefficient yang diterapkan pada metode perhitungan boothstrapping. Hasil tersebut akan diuraikan pada tabel sebagai berikut.

Tabel 9. Hasil Pengujian Hipotesis

\begin{tabular}{|l|c|c|}
\hline \multicolumn{1}{|c|}{ Variabel } & T-Statistic & $P$-Value \\
\hline Citra Merek -> Minat Beli & 7.017 & 0.000 \\
\hline E-WOM -> Minat Beli & 1.901 & 0.058 \\
\hline Penggunaan Media Sosial -> Minat Beli & 2.731 & 0.007 \\
\hline
\end{tabular}

Sumber: Data diolah dari Smart PLS 


\section{KESIMPULAN}

Berdasarkan hasil dan pembahasan di atas mengenai pengujian variabel penggunaan media sosial, citra merek dam E-WOM terhadap minat beli konsumen generasi Y dan Z KFC Citra Garden 6 maka dapat disimpulkan sebagai berikut:

1. Citra merek berpengaruh signifikan dan positif terhadap minat beli pada konsumen generasi Y dan Z di KFC Citra Garden 6, Jakarta Barat.

2. E-WOM tidak berpengaruh signifikan tetapi berpengaruh positif terhadap minat beli pada konsumen generasi Y dan Z di KFC Citra Garden 6, Jakarta Barat.

3. Penggunaan Media Sosial berpengaruh signifikan dan positif terhadap minat beli pada konsumen generasi Y dan Z di KFC Citra Garden 6, Jakarta Barat.

\section{DAFTAR PUSTAKA}

Ajzen, I. (1991). The theory of planned behavior. Organizational behavior and human decision processes, 50(2), 179-211.

Indika, D. R., \& Jovita, C. (2017). Media Sosial Instagram Sebagai Sarana Promosi Untuk Meningkatkan Minat Beli Konsumen. Jurnal Bisnis Terapan, 1(01), 25-32

Jalilvand, M. R., \& Samiei, N. (2012). The Effect Of Electronic Word Of Mouth On Brand Image And purchase Intention. Marketing Intelligence \& Planning.

Putra, Y. S. (2017). Theoritical review: Teori perbedaan generasi. Among Makarti, 9(18).

Rifai, H. A., Kumadji, S., \& Yulianto, E. (2016). Pengaruh Perluasan Merek Terhadap Citra Merek Dan Dampaknya Terhadap Minat Beli (Survei Pada Pengguna Produk Induk Merek Lifebuoy Pada Mahasiswa S1 Dan D3 Universitas Brawijaya). Jurnal Administrasi Bisnis, 35(1), 120-126.

See-To, E. W., \& Ho, K. K. (2014). Value Co-Creation And Purchase Intention In Social Network Sites: The Role Of Electronic Word-Of-Mouth And Trust-A Theoretical Analysis. Computers in Human Behavior, 31, 182-189.

Setiawati, M., \& Aida, W. (2017). Pengaruh Media Sosial Terhadap Minat Beli Konsumen Studi Kasus Mahasiswa Manajemen Universitas Pasir Pengaraian. Jurnal Mahasiswa Prodi Manajemen Fakultas Ekonomi, 2(2). 
Setiawaty, N. A. (2017). Pengaruh Iklan, Citra Merek, Dan Kepercayaan Merek Terhadap Minat Beli Konsumen Smartphone Samsung Galaxy Series (Studi Kasus Mahasiswa/I Universitas Gunadarma, Depok). Jurnal Ilmiah Ekonomi Bisnis, 22(1).

Widjaja, A. T. (2016). Pengaruh Word Of Mouth Dan Electronic Word Of Mouth Terhadap Purchase Intention: Sebuah Studi Kasus Mengenai Perilaku Konsumen Terhadap Jasa Ojek Online Gojek. Jurnal Bisnis dan Manajemen, 53(12). 